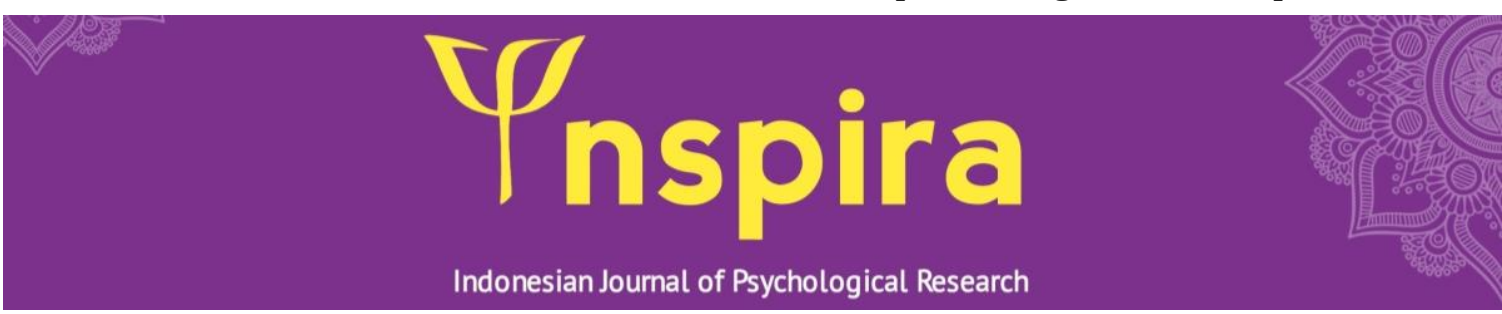

\title{
Emotional maturity of early age marriage's woman
}

\author{
Farahdiba Thahura ${ }^{凶}$
}

Department of Guidance and Counseling, Universitas Sains Cut Nyak Dhien, Aceh, Indonesia;

\section{${ }^{\otimes}$ Corresponding author: \\ Farahdiba Thahura (email: farahdibatahura@gmail.com)}

\begin{abstract}
Marriage is quite interesting to talk about more and more at this time because at this time many problems arise related to marriage because marriage is a complicated and complex thing. There are many things to be prepared for before someone decides to enter the marriage level, especially for a wife. The purpose of this study is to assess the extent of the role of emotional maturity of young wives in creating harmony in the family. Respondents in this study were women, aged 18-20 years in Aceh, marriage period of $0-3$ years. The number of respondents is 2 people using qualitative research methods. The method of data collection in this study is by observation and interview using tape recorder tools and observation sheets. These internal and external factors affect whether or not the respondent is mature emotionally. This emotional immaturity is a reaction seen in every respondent. The maturity of respondents is different from each other. The respondents were aware of the impact on marriage at a young age but did not make the respondents dissolve in any conflicts that occurred due to immature emotions of the respondent, but rather made efforts to be able to control and overcome all conditions faced wisely and try to make positive efforts to foster family harmony.
\end{abstract}

\section{Article History:}

Received: January 3, 2020

Revised: February 5, 2020

Accepted: March 11, 2020

Published: June 18, 2020

\section{Keyword: \\ Aceh woman; early marriage; emotional maturity; immaturity}

\section{How to cite (APA 7th Edition)}

Thahura. F. (2020). Emotional maturity of early age marriage's woman. INSPIRA: Indonesian Journal of Psychological Research, 1(1), 19-24. https://doi.org/10.32505/inspira.v1i1.1720

This is an open-access article distributed under the Creative Commons Attribution License, which permits unrestricted use, distribution, and reproduction in any medium provided the original work is properly cited. This is enabled under the terms of attribution and noncommercial usage of the material.C2020 by Farahdiba Thahura 


\section{INTRODUCTION}

Marriage is quite interesting to talk about more and more at this time because at this time many problems arise related to marriage because marriage is a complicated and complex thing. Complicated because marriage is as easy as many people imagine, and complex because marriage concerns many facets. Many things must be prepared before one decides to enter the marriage level, especially for a wife. Duval \& Miller (1985) states that one of the things that must be prepared before entering the marriage level is the ability to master oneself emotionally.

Mappiare (1983) states that emotional maturity has a big influence on the robustness of domestic marriage. Harmony according to Gunarsa (1995) is always related to the situation of a household/family in marriage. A family who has emotional maturity will be more flexible and easy to accept changes, such circumstances are very necessary to overcome the problems that must be taken in daily life.

Hurlock (2004) that emotions can provide color for human life. Feelings of pleasure, hate, joy, sadness, and anger can be expressed through the expression of emotions that arise at times where the individual must be able to adjust between emotions to the situation or place in which the individual is located. Chaplin (2008) stated that emotions are when circumstances include conscious changes, deep in nature, and behavioral changes. Emotions can also master motivated behavior. Emotions are usually evoked by external events and emotional reactions are shown at these events (Atkinson, Richard \& Hilgard, 1996). According to Goleman (1999), emotion is a typical feeling and thoughts, a biological, and psychological state, and a series of tendencies to act.

Emotional maturity is important to see if a person has been able to escape from dependence on parents or others who have been dominant in their lives. If a wife still trusts or puts her old family first in every problem, or a husband who cannot escape from the care, guidance, and assurance of his parents, then the husband and wife will not succeed in forming a family bond.

Hawari (2006) states that marriage is a bond between a man and a woman as husband and wife based on applicable laws, religious laws, or customs. In the term of Islam, marriage means "to gather" or "collect" which is one of the efforts to channel the sexual instincts of husband and wife in the household, as well as a means to produce offspring that can guarantee the continuity of human existence on the earth.

Marriage is the inner birth bond between a woman and a man. Between emotional maturity and marriage, it is like having a close relationship so that the problems in the household itself can be seen properly and objectively. Walgito (2002) the recommended age in marriage as an ideal age, reviewed psychologically in women aged 23-24 years and men aged 26-27 years. In those ages in general psychological maturity has been achieved, especially emotional maturity.

A wife is a structure that includes customs, manners, laws, and other norms both rational and irrational around parenting and raising children. Hawari (2006) describes a good wife as a wife who serves and takes good care of her husband, meekness, and affection. Meanwhile, marriage counselors often add that a good wife is graceful in public, frugal in the kitchen, and warm in bed. It is also explained that the wife organizes and arranges daily household needs as best as possible.

The description of the picture of the wife above certainly prepares for the marriage itself should be considered well, especially for wives who marry at a young age. Emotional maturity is 
one of the important aspects that must be thought about before marriage to create family harmony. The above opinions and problems encourage the author to know how the emotional maturity of a young wife to achieve harmony in marriage. Therefore, the purpose of this study is to assess the extent of the role of emotional maturity of young wives in creating harmony in the family.

\section{RESEARCH METHOD}

A qualitative approach is seen as more appropriate to know how the phenomenon of the number of young women to choose to marry at a young age. According to Patton (in Poerwandari, 2001) qualitative design has flexible properties, therefore there are no definite rules in the number of samples to be taken for qualitative research. The number of samples depends largely on what is considered useful and can be done with the time and resources available.

In this study, the method of data retrieval was conducted with interviews and observations. Respondents This study numbered 2 respondents (IC and MV) with characteristics of female respondents, aged 18-20 years, domiciled in Aceh, marriage period 0-3 years. The sampling procedure in this study is based on theory-based operational construct sampling. This study will be conducted at the respondent's home. The interview process can be conducted directly at the location according to the respondent's will.

The tools used in this study are interview guidelines and a recording device that is a tape recorder and observation sheet. The position of researchers in qualitative research is quite complicated, for that it is necessary to use research instruments or tools to help researchers in collecting data (Moleong, 2013). Qualitative research data is not in the form of numbers, but more in the form of narratives, stories, written and unwritten documents (pictures or photos), or other non-numerical forms.

\section{RESULT}

When entering the marriage level, respondents tend to be emotionally immature. This can be seen from the symptoms that can be seen from the respondents, among others: first, the fickle emotions, namely explosive behavior in responding to a stimulus faced (uncontrolled), can not accept criticism. Second, relying too heavily on others tends to be easily influenced and makes hasty decisions. Third, expect stimulation or stimulation that demands a lot of attention and can't wait to face something. Fourth, egocentric self-centeredness where the individual is more selfish.

In response to the above, describing respondents who tend to have emotional immaturity. The immaturity of respondents is reflected in the conflict in the household and the lack of harmony in marriage. Things that are factors in the absence of emotional maturity from respondents are influenced among others by internal and external factors. Internal factors consist of emotional states where at a young age, the emotional state of each respondent is still unstable, then cooperation, friendship, and willingness, where the subject inevitably has to have tolerance and cooperate in fostering a new relationship with a partner, this tends to be difficult to do because at that age is the period in which the respondents try to find their identity.

While external factors are influenced by: first, influenced by physical factors, at a young age respondents tend not to be able to control well their emotions against hormonal changes that 
occur for example at the time of menarche, then, patterns of control over emotions, respondents tend not to be able to control emotions fairly and by social expectations, respondents tend to do things that suit themselves only, then intelligence.

this factor also influences because it affects respondents in giving assessments of others and environmental situations, but it also has an effect to gain insight in solving emotional problems more greater, and the last is age, although age affects emotional maturity, in each individual, the level is not necessarily the same. This is influenced by many other factors such as parenting patterns, social environment, education and so on.

These internal and external factors affect whether or not the respondent is mature emotionally. This emotional immaturity is a reaction seen in every respondent. The maturity of respondents is different from each other. The respondents were aware of the impact on marriage at a young age but did not make the respondents dissolve in any conflicts that occurred due to immature emotions of the respondent, but rather made efforts to be able to control and overcome all conditions faced wisely and try to make positive efforts to foster family harmony.

\section{DISCUSSION}

Both respondents in this study, IC and MV, had different backgrounds when deciding to marry young. At that time IC wanted to marry young because she felt ready to enter the marriage level. The subject also married young on the grounds of not wanting to sin and trying to keep the good name of the parents. In addition, the age of a more mature and more established partner makes the subject not hesitate to decide to marry at a young age. The readiness of the subject to marry young is also supported by the family. The family provides support by giving the subject the freedom to marry.

Unlike IC, MV married on the grounds of getting pregnant before marriage. MV marriage that was forced to do, caused complex problems, among which the subject lost her youth because of having to marry and take care of the household, in addition, the subject also experienced stress due to losing time studying and playing as did her age friends. Free association is one of the factors of young marriage. Less supervision and freedom from parents also cause the subject to be detached from parental supervision. In addition to the above, one of the other factors is the existence of a supportive environment. The subject's free social environment reinforces free association behavior. The number of peers who experience the same thing becomes a kind of defense of the subject against the actions.

This is in line with Adhim's statement (2002) that there are 3 factors of individuals deciding to marry at a young age, namely: the first factor is based on a high moral awareness of religion to protect themselves from derogatory acts, for example, because they already feel like and to avoid themselves from unwanted things or because they are ready to build a home. The second factor is due to compulsion, for example, due to the coercion of the family, the state of the middle and lower economy, or because of pregnancy outside marriage. While the third factor is due to the average environment of carrying out marriage at a very young age.

In MV, the condition of the subject and the partner who was not yet established both physically and mentally cause a lot of conflict in marriage. Problems that occur, among others, economic problems, this becomes a problem because the couple is not yet financially established and still very dependent on parents, the division of responsibilities between taking care of family 
and college, self-adjustment in the face of a new environment that suddenly entered the subject because of having to live with in-laws, husband habits that do not meet the expectations of the subject and many other things. As said by Hawari (2006) that marriage at a young age, certainly considered not to have passed the stage of development perfectly. In addition, at a young age, an individual is considered incapable of being responsible for taking care of others in his or her life. There is no readiness to conceive, give birth and educate children.

Judging from the character of each respondent, both have relatively the same character. IC, in the family environment, was classified as a spoiled child. The single child factor in the family is one of the reasons. The needs of the subject are relatively fulfillable. Subjects tended to get more attention and affection from the surrounding environment, both family and friends. The subject's jolly character causes the subject to get along easily with the surrounding environment. The subject had also been taught independence from parents since before marriage, for example, the subject is allowed to work and hang out with her friends. After marriage, subjects tended to still have a dependence on parents, but not directly. For example, the subject still lives in a house with both parents after marriage, but the subject still has the will to live independently with the husband without being bound by parents.

IC could be said to be immature emotionally, this is because, among others, IC still has fickle emotions, IC had not been able to control its emotions well and has not been able to understand the problems that arise more objectively. Impulsive IC characters sometimes caused conflicts in the household. This is reinforced by Murray's statement about the characteristics of emotional immaturity. IC met some of the characteristics of emotional immaturity. IC's characters that are a little temperamental and spoiled were balanced by the character of the pair who tend to be more mature. This could at least dampen the conflict that occurs in the household. IC's home life relatively does not have too much pressure.

Compared to IC, MV tended to be more emotionally mature. The pressures and problems she faced in marriage led to the subject being wiser in dealing with each problem. Problems arising in her marriage make the subject calmer and able to control her emotions well. The subject is also aware of the impact she would face when deciding to get married. This made the subject more responsible and strives to live the marriage as best and positively as possible. Poor marital conditions also did not make the subject give up and depressed, but rather make the subject more mature than before. the subject also strives to always give the best assessment of all problems that arise and accept themselves and spouses as they are. In this regard, there is no denying that the subject has emotional maturity in her marriage, as stated by Walgito (2002), the subject has fulfilled some characteristics of individuals who have emotional maturity.

\section{CONCLUSION}

The condition of both respondents who are both young when married certainly gives rise to certain polemics. The young age, which is said to be physically and psychologically immature, makes the marriage vulnerable to conflict. The influence of emotional maturity is enormous, as stated above, in the presence of emotional maturity, the subject can dampen the conflict that occurs. The subject can also calm down and direct his emotions more positively. In addition, emotional maturity serves as a bridge for couples to see the problem more objectively so that the solution taken is also beneficial for the integrity of the household. Emotional maturity also 
makes marriage more harmonious, this is due to individuals who have emotional maturity able to understand the partner and able to resolve conflicts as quickly as possible in their household. Conversely, emotional immaturity can harm a marriage. Many conflicts cannot be viewed objectively and cannot properly solve problems. The personal ego that arises causes conflict cannot be responded to calmly. Prolonged conflict and stress in a marriage ultimately cause the couple to become disharmonious and potentially lead to divorce.

After conducting the research, the authors realized there were still many shortcomings in the research process, such as lack of rapport, interviews, and observations that were less in-depth and also the least number of informants in the study. This leads to less rich and comprehensive results.

\section{REFERENCES}

Adhim, M. F. (2002). Indabnya menikah usia muda. Gema Insani.

Atkinson, R., Richard, A., \& Hilgard, E. (1996). Introduction to psychology. Harcourt Brace College Publishers.

Chaplin, J.P. (2008). Kamus lengkapp psikologi. RajaGrafindo Persada

Duvall, E. M. \& Miller, B. C. (1985). Marriage and family development $6^{\text {th }}$ ed. Harper \& Row Publisher, Inc

Goleman, D. (2007). Kecerdasan emosional. Gramedia Pustaka Utama

Gunarsa, S. D. (1995). Psikologi untuk keluarga. Gunung Mulia

Hawari, D. (2006). Manajemen stress cemas dan depresi $2^{\text {nd }}$ ed. Balai Penerbit Fakultas Kedokteran Universitas Indonesia

Hurlock, E. B. (2004). Psikologi Perkembangan. Gramedia Pustaka Utama

Mappiare, A. (1983). Psikologi Orang Dewasa. Usaha Nasional.

Moleong, L. J. (2013). Metode penelitian kualitatif. Remaja Rosdakarya

Poerwandari, K. (2005). Pendekatan kualitatif untuk, penelitian perilaku manusia. Fakultas Psikologi Universitas Indonesia

Walgito, B. (2002). Bimbingan dan konseling perkawinan. Andi Offset 